\title{
A DYNAMIC PERSPECTIVE ON L2 PRONUNCIATION DEVELOPMENT: BRIDGING RESEARCH AND COMMUNICATIVE TEACHING PRACTICE
}

\section{UMA PERSPECTIVA DINÂMICA DO DESENVOLVIMENTO DA PRONÚNCIA DE L2: CONECTANDO PESQUISA E PRÁTICA DE ENSINO COMUNICATIVO}

\author{
Ronaldo Mangueira LIMA JR. ${ }^{1}$
}

Ubiratã Kickhöfel ALVES²

\begin{abstract}
The main goal of this paper is to raise language teachers' awareness of the need to incorporate research-based pronunciation teaching into their communicative language classes in an ongoing and integrated manner. To do so, we begin by characterizing language and its learning process as dynamic systems, which develop over time through the constant interaction of their agents. Then we review current studies on L2 sound production and perception as well as on the explicit teaching of L2 pronunciation under a dynamic perspective in the Brazilian scenario. Finally, we suggest a few general directions and guiding principles for pronunciation teaching, showing that it is possible to include pronunciation instruction in communicative language teaching.
\end{abstract}

Keywords: Phonetics. Pronunciation Teaching. Second Language Acquisition. Complex Dynamic Systems.
Resumo: O principal objetivo deste artigo é o de conscientizar professores de línguas para a necessidade de se incorporar, de maneira integrada e contínua, o ensino de pronúncia, baseado em pesquisas da área, ao ensino comunicativo de línguas. Para alcançar esse objetivo, começamos caracterizando língua e o seu processo de aprendizagem como sistemas dinâmicos, que se desenvolvem através do tempo pela constante interação de seus agentes. A seguir, revisamos pesquisas recentes sobre produção e percepção de sons de L2, bem como sobre o ensino explícito da pronúncia de L2 sob uma perspectiva dinâmica, desenvolvidas no contexto brasileiro de investigações. Por último, sugerimos algumas diretrizes e princípios gerais para o ensino de pronúncia, mostrando que é possível incluir a pronúncia ao ensino comunicativo de línguas.

Palavras-chave: Fonética. Ensino de Pronúncia. Aquisição de Segunda Língua. Sistemas Complexos Dinâmicos.

\footnotetext{
1 Lima Jr. UFC. E-mail: ronaldojr@letras.ufc.br. ORCID ID: https://orcid.org/0000-0002-8610-0306. 2 Alves. UFRGS. E-mail: ukalves@gmail.com. ORCID ID: https://orcid.org/0000-0001-6694-8476.
} 
- A dynamic perspective on L2 pronunciation development: bridging research and communicative teaching practice

\section{Introduction}

In this paper, we address one of the least studied components in L2 teaching and research: pronunciation. Despite its unquestionable role for intelligible communication, pronunciation has had many ups and downs throughout the history of foreign language teaching methods. Currently, pronunciation seems to be a regular component of Communicative Language Teaching (e.g. CELCE-MURCIA, 2001; RICHARDS; RENANDYA, 2002), present in most textbooks, language course prospects and teacher training materials. However, pronunciation is also one of the teaching components frequently neglected by teachers due to lack of confidence, the need to cover grammar and vocabulary for testing purposes, and the lack of L1-specific pronunciation practice in textbooks designed for a worldwide audience, among other reasons (cf. SILVEIRA, 2004, 2016).

Given that there cannot be intelligible oral communication without proper pronunciation and that pronunciation teaching tends to be neglected by some language teachers (cf. DERWING; MUNRO, 2015 a, b; MUNRO, DERWING, 2015; LEVIS, 2018), our most important goal with this paper is to bridge the gap between research on L2 phonetic-phonological development and pronunciation teaching practice, as a means to empower language teachers to incorporate pronunciation instruction into their classes in a contextualized, communicative and integrated fashion. Teachers' beliefs and assumptions regarding the process of language learning have a tremendous influence on their classroom practice. Language teachers bring their knowledge, beliefs and experiences concerning language learning embedded in their lesson plans, in their teaching practice, and in their pedagogical choices and decisions. Thus, we believe that a clear understanding of the process of language learning and, especially, of L2 pronunciation development is of paramount importance for language teachers. With a clearer concept of language development in mind, teachers are enabled to reflect upon the factors that influence the complex process of L2 pronunciation development and, as a result, are better equipped to make principle-based, rather than intuition-based decisions concerning their (pronunciation) teaching practice.

In order to bridge the gap between research and teaching practice, we are also going to argue that, among the many views and perspectives of language and of foreign language learning, the theoretical perspective of Dynamic Systems Theory (DST) applied to foreign language learning (LARSEN-FREEMAN, 1997, 2014, 2015a, 2015b, 2017; CAMERON, 2003; LARSEN-FREEMAN; CAMERON, 2008; BECKNER et al., 2009; DE BOT, 2017, 2008; DE BOT; LOWIE; VERSPOOR, 2007; DE BOT et al., 2013; LOWIE, 2017; LOWIE; VERSPOOR, 2019; 2015 ) is well suited to account for phonological development. We intend to show that the 
main tenets of DST are able to connect the results of recent research on pronunciation teaching and learning to more effective L2 classroom practices.

This paper is divided in three main sections. In the first section, we present the main tenets of Dynamic Systems Theory and its application to phonological acquisition and pronunciation teaching. In the next section, we review recent studies on pronunciation teaching carried out under the same theoretical perspective. Then, in the last section, based on the principles and on the results of the research studies we report throughout the text, we suggest a few research-based pronunciation pedagogical practices that could be implemented in the foreign language communicative class.

\section{The dynamic perspective of pronunciation teaching}

Dynamic Systems Theory (DST), also referred to as Complexity Theory or Complex Dynamic Systems Theory, is based on Chaos Theory and has arisen in the exact sciences, with a focus on mathematics and physics. However, now it has applications to virtually every science, including, but not limited to, biology, meteorology, medicine, economy, oceanography, engineering, education and literature. Its applications in cognitive science appeared with proposals by Thelen and Smith (1994), Port and Van Gelder (1995), Port (2002), among others. In the field of language development, the earliest contribution is probably that of Articulatory Phonology, proposed by Browman and Goldstein (e.g. 1989a, 1989b, 1992), followed by that of Connectionism for language acquisition (e.g. COOPER, 1999; ELLIS, 1998; ELMAN, 1995). In Second Language Acquisition (SLA), the pioneering work was Larsen Freeman's 1997 seminal paper, which has paved the way for further work (e.g. CAMERON, 2003; DE BOT; LOWIE; VERSPOOR, 2007; DE BOT, 2008; SILVA, 2003; VERSPOOR; LOWIE; VAN DIJK, 2008).

Dynamic Systems Theory (DST), as the name suggests, studies the nature and behavior of Dynamic Systems, which are typically complex, dynamic, non-linear, selforganizing, open, emergent, sometimes chaotic, and adaptive. Many systems in the world are dynamic, such as the movement of crowds exiting a stadium, weather changes, the stock market valuation system, and the sudden success of internet videos and fads, just to mention a few. For what concerns this paper, we join the scholars aforementioned in arguing that language and its development are dynamic systems. Therefore, in the paragraphs below, we aim to characterize these systems with a special reference to SLA and to second language phonological development. 
- A dynamic perspective on L2 pronunciation development: bridging research and communicative teaching practice

Firstly, Dynamic Systems are complex. In the theory, complex refers not only to the fact that the system is composed of various elements or agents, but especially to the fact that its behavior is beyond the sum of the behaviors of its individual agents. The behavior of a dynamic system is not found in its individual components; rather, it emerges from the iterative and interconnected interactions of its components among themselves and with the environment, whose results are unpredictable. Chaos in complexity theory is not lack of order, but rather unpredictability (DE BOT, 2008). Language is composed of subsystems, like morphology, phonology, syntax, semantics, pragmatics, etc., which are interdependent and interact with one another and with the environment, forming larger L1 and L2 subsystems that interact with one another (LOWIE; VERSPOOR, 2015). Therefore, language and its communicative function emerge from the iterative interaction of all its components, with one change in a subsystem potentially provoking changes in all other subsystems and in the system as a whole. As a result, one can already foresee the holistic and interconnected approach to pronunciation teaching we are going to defend, for pronunciation only truly exists within the language and within its communicative function.

Unsurprisingly, Dynamic Systems are also dynamic, which implies their constant change in time. In such systems, processes are more important than products, for their dynamic nature prevents them from reaching a final state. This characteristic challenges the possibility of SLA ever reaching a final state, that of the so-called ultimate attainment or native-likeness. Rather, DST views SLA as an ongoing, dynamic and never-ending process. Even the terms target language and language acquisition are questioned in a dynamic perspective, for dynamic systems simply do not have an end-state target. That is the reason we favor the term Second Language Development (SLD) over acquisition or learning (cf. LARSEN-FREEMAN; CAMERON, 2008, among many others). Also, we readdress this issue in the final section, when we discuss the goal of pronunciation teaching.

Another characteristic of Dynamic Systems is that they are non-linear, meaning that causes and effects do not share a one-to-one relation, as is the case of linear systems. At the same time that some snow, for instance, may not cause anything when it falls on a mountain, a little pebble might cause an avalanche. This is also known as the "butterfly effect", coined by Lorenz (1972) when questioning if (or rather, suggesting that) the flap of a butterfly's wings in Brazil could cause a tornado in Texas. On the other hand, some great action may have very little - or even no effect at all. As De Bot, Lowie and Verspoor (2007, p. 8) put it: 
There is a non-linear relation between the size of an initial perturbation of a system and the effects it may have in the long run. Some minor changes may lead to huge effects, while major perturbations may be absorbed by the system without much change.

The non-linear relation between cause and effect is illustrated by Bak and Weissman (1997) through the image of someone dropping sand on a surface. In the beginning, it is possible to drop several grains of sand, one onto the other, with the sand forming a coneshaped pile. However, as more grains are added to the system, the pile becomes steeper and steeper, and the system reaches a critical point, at which one small grain may cause an avalanche, which, in turn, may also cause other avalanches, and these avalanches cannot be predicted in number or dimension. This is due to the fact that dynamic systems are sensitive to initial state, which is responsible for the non-linearity and non-predictability of the effects. Different initial states and their interactions with the components of the system can take the whole system through different paths. Dynamic systems in a critical state, such as that of the pile of sand, are characterized by high instability and unpredictable behavior. This illustrates the non-linear relation between the perturbation (grains of sand) and the results (avalanches).

As Johnson (1997) puts it, a linear relation is like the volume knob on a radio, with each and every nuance of change on the knob causing the same change in volume. A nonlinear relation, on the other hand, is like the tuning knob on a radio, for at the same time that a small change on the knob might cause a great effect (getting one out of a station), great changes might also have no result at all (as when navigating through static radio frequencies).

If SLD were a linear system, this would mean that every item taught by the teacher would be learned by all students at the same time, but this is clearly not the case. The nonlinearity between teaching and learning is also present in the fact that language learning does not happen item by item, with the learner having to completely master one item before being able to move on to the next one. The developmental process has peaks and valleys, progress and backslides. This way, the same pedagogical action, such as a pronunciation-based lesson or activity may take the learners to different outcomes in the long run, and their outcomes might come at different moments depending on the state of their own systems at the time of the lesson.

Since dynamic systems are sensitive to initial states, any pedagogical intervention will be influenced by the various learner variables at play, such as students' age, motivation, exposure to L2, knowledge of another foreign language, level of literacy in the L1, socio- 
- A dynamic perspective on L2 pronunciation development: bridging research and communicative teaching practice

economic and cultural levels, amount of feedback received, types of instruction received, etc., which completely influence the developmental process, making L2 learners from the same class/course/school develop non-linear learning routes and, thus, get to the end of their language course with diverse proficiency levels in the L2. The complexity of the 22 developmental system lies in the fact that none of the learners' characteristics can, separatedly, determine the system or its development due to the constant interaction of the many characteristics of each individual learner within him/herself and with the environment.

MacIntyre et al. (2017) highlight not only that similar initial conditions may lead to completely different results (cf. HIVER, 2015), but also that different initial stages may converge in similar results at some specific stage of development (IRIE; RYAN, 2015). Even though two individuals might exhibit two very distinct initial conditions, it is undeniable that, throughout their developmental processes, "there are predictable tendencies in human development, usually referred to as 'stages'" (VERSPOOR, 2015, p. 39). These stages are a consequence of the movement of the system towards attractor states, which attempt to bring order and some stability to the system. Seen as 'places where the system settles' (LARSEN-FREEMAN, 2015a, p. 12), attractors are temporary and non-fixed, with different attractors demanding more or less energy to dislocate the system. De Bot, Lowie and Verspoor (2007) compare this movement with that of a small ball on a surface with some holes. As we tilt the surface, the ball might get out of one hole and stop on another, and the bigger and deeper the hole, the more we will have to tilt the surface to get the ball out of it; hence, more energy will be needed to take the ball from one attractor state to another.

What is traditionally conceived of as "fossilization", for instance, may rather be seen as an attractor. Therefore, even though it sometimes demands a lot of energy, it is always possible to get out of this attractor state. Fortunately, and contrary to what is implied by the jargon "fossilization", attractor states are not an end in themselves; they are potentially temporary and transitory. In L2 phonological development, it is possible that L2 learners associate miscomprehended L2 sounds to L1 sound categories and that these associations become attractor states that demand a lot of energy for the system to move towards another attractor state that contains the appropriate sounds. Consequently, L2 development tends to be gradual and, at times, has abrupt changes, which show the (re) structuring attempts of the system through self-organization towards attractors.

The learner's L1 creates several attractor states along the way at all levels of language, including phonology. In phonological development, learners' L1 sound categories function as attractor states, leading students into categorizing an L2 sound that does not occur in 
their L1 into a L1 prototypical category, usually the phonetically closest one (FLEGE, 1995). That is why Brazilian learners might categorize both English [i:] and [I] or [ $[\varepsilon$ ] and [æ] into their Brazilian Portuguese [i] and [ $\varepsilon$ ], respectively, or why they might categorize $[\theta]$ into $[t]$, [f] or [s]. Each element of a dynamic system may have its own attractors, and its interactions with these attractors make global patterns emerge. The development of a dynamic system occurs from the interaction of its components and from self-organization.

The emergence of global patterns from local interactions is also present in phonology in the relation between articulatory effort and acoustic results as well as in the relation between acoustic results and semantic contrast. Actually, the fact that languages use a limited number of contrasts among words when compared to the number of articulatory possibilities, especially because articulation is gradient in nature, has been the focus of many phonological models, which ends up creating an unnecessary gap between phonetic and phonological studies. Through Articulatory Phonology, Browman and Goldstein (e.g. 1995, 1992, 1991, 1990, 1989a, 1989b, 1988) proposed a model to phonological representation and analysis based on DST, in which the decrease from the articulatory possibilities to what is actually used in a language can be interpreted as the selforganization of the system. Under this proposal, the macroscopic patterns of phonology are seen as an attractor state resulting from the self-organization of the interactions in the microscopic (phonetic) realm.

In articulatory phonology, the primitive unit is the articulatory gesture, a dynamic unit of articulatory action, whose physical results can be seen in the movement of the articulators. It is "an abstract oscillation that specifies constriction in the vocal tract and induces the movements of the articulators" (ALBANO, 2001, p. 52). Browman and Goldstein have modeled the gesture through Saltzman and Kelso's task dynamics (KELSO; SALTZMAN; TULLER, 1986; SALTZMAN; KELSO, 1987), which is a motricity model that defines the movement not from individual movements of elements, but from the task to be accomplished, which, in this case, has been used to model the coordinated multiarticulatory actions of speech. In one of its central issues, task dynamics states that it is not the individual movements of the articulators that define speech dynamics, but rather the movement of the tract variables under a dynamic systems perspective. Albano (2001, p. 43) sustains that the gesture "is materialized not in the effective movements of the articulators, but in invariant commands for the implementation of these movements in real time in the vocal tract".

The attentive reader might have once again anticipated the holistic, interconnected and interactive approach to pronunciation teaching we are going to advocate in the 
- A dynamic perspective on L2 pronunciation development: bridging research and communicative teaching practice

sections to come, for articulation is only realistic when interacting with other articulations in order to achieve a task. Interaction and task here can be seen at both their most physical meaning, in generating sound, and their functional, communicative meaning.

In the following section, we review some current studies on pronunciation development research and on pronunciation teaching research conducted under a DST perspective in Brazil.

\section{$\mathrm{L} 2$ pronunciation research in Brazil: a dynamic account}

In the last few years, many studies on the development of L2 sound systems have been carried out in Brazil and abroad. These studies vary with regard to the aspects and themes of investigation, ranging from the perception and production of L2 sounds to the intelligibility of L2 speech and the role of explicit instruction/perceptual training. In what follows, we will concentrate on the main studies carried out in Brazil and also discuss how a dynamic perspective of L2 pronunciation has guided and contributed to the main findings of these studies.

As for the production of L2 sounds, several studies have focused on the many learner variables that play an important role in language development. From these studies that follow a dynamic perspective, we can refer to the investigations carried out by Lima Jr. $(2015,2012)$, who concentrated on age effects in the development of the vowel system of English by Brazilian learners; Barboza (2013), who focused on the role played by two different L1 dialects of Brazilian Portuguese in the development of English; CristófaroSilva and Rodrigues (2015) and Cristófaro-Silva and Camargos (2016), who investigated the developmental process of the final /I/ and rhotics, respectively; Blank $(2016,2013)$, who investigated the development of a third language system and the effects of the L1 and L2 systems in the learning of this L3; Pereyron and Alves (2016) and Pereyron (2017), who compared the Spanish produced by bilingual Argentineans living in Brazil with that of monolinguals living in Argentina, showing additional language effects over the L1 systems of the participants living in Brazil; Kupske (2016); Schereschewsky; Alves; Kupske (2017), De Los Santos (2017), De los Santos and Alves (2018), who have shown L2 effects on the L1 subsystem in both dominant and non-dominant L2 environments; Nascimento (2016), who showed that the emergence of a variable process in the learners' $\mathrm{L} 1$ may play a role in L2 development, by redefining these learners' initial conditions.

The results obtained from these studies confirm the role played by learners' variables, as they suggest that: (i) although age effects seem to be found in learners' data, the difficulties in the development of L2 vowels are not a matter of "all or nothing", as 
gradience can be found in the emergence of new phonological patterns (cf. LIMA JR., 2008; 2015; CRISTÓFARO-SILVA; RODRIGUES, 2015; CRISTÓFARO-SILVA; CAMARGOS, 2016); (ii) different L2 dialects might result in distinct developmental paths, and a longitudinal study of learners' data reveals important developmental aspects that would have been disregarded under a more traditional cross-sectional account (BARBOZA, 2013; NASCIMENTO, 2016); (iii) not only the L1, but also the L2 system plays a role in L3 development (BLANK, 2013, 2016); and (iv) the L2 and L3 subsystems can also affect the learners' L1 (PEREYRON; ALVES, 2016; KUPSKE, 2016; PEREYRON, 2017; DE LOS SANTOS, 2017; DE LOS SANTOS; ALVES, 2018). The results from these last two sets of studies reinforce the dynamic assumption that an alteration in one of the language subsystems may affect the linguistic system as a whole.

Several other studies on L2 production have also shown that L2 accented speech should not be explained in an "all or nothing" fashion or by a description that relies dichotomically in the presence or absence of a given segment or feature. As stated in the previous section, learning an L2 sound system implies the ability to "orchestrate time" (cf. ZIMMER; ALVES, 2010), that is, the learning of timing relations between articulations in order to achieve the articulatory task. Ferreira (2007) presented one of the first graduate studies in Brazil that reinforced the importance of learning time relations in a dynamic perspective of L2 development. In a series of follow-up studies (FERREIRA, 2007; ENGELBERT; SILVA, 2012; ENGELBERT, 2014), the author investigated the production of minimal pairs such as 'pop/poppy' and 'bob/bobby' by Brazilian learners. In the 2012 study, students' productions of 'poppy' and 'bobby' were compared to those of native speakers of American English. The results indicated a significant difference between the productions of the two groups, as Brazilian learners tended to produce much shorter vowels than the native speakers did. In other words, neither the productions of 'pop' (with or without an epenthetic vowel) nor the productions of 'poppy' could be rendered equal to those of native speakers. All these patterns exhibit different temporalities, which, in a dynamic perspective, constitute a key factor in second language development.

The challenge of orchestrating time is also salient in other studies that investigated the voicing of stop segments, both in word-initial and in word-final positions in English. As for voicing in word-initial position, studies on the development of the VOT ${ }^{3}$ patterns of English by Brazilian learners (FRANÇA, 2010, 2015; SCHWARTZHAUPT, 2012; PRESTES, 2013; ALVES; ZIMMER, 2015) indicate that students' productions should not be characterized by the binary 'presence' or 'absence' of aspiration, since Voice Onset Time was acquired

3 Voice Onset Time refers to the duration between the release of a stop consonant and the onset of voicing of the following vowel. Languages vary in their VOT values in voiced and voiceless plosives. 
- A dynamic perspective on L2 pronunciation development: bridging research and communicative teaching practice

gradually and depended on a multitude of linguistic and learners' variables. These studies also indicate that, even in lower proficiency levels, learners produced longer VOT values in the target language than in their L1. As for word-final position, Zimmer and Alves (2012) showed that both native speakers and learners of English exhibited partial voicing in the production of final stops; this partial voicing, which was reinforced by a difference in the length of the previous vowels, proved relevant in the distinctions of minimal pairs such as 'bat-bad' or 'cap-cab'. Similar results have been found by Batista (2018), who investigated the development of minimal pairs ending in the alveolar fricative, such as 'ice-eyes'. Therefore, a binary, categorical explanation of the $L 2$ data would not be enough to account for L2 development.

In tandem with investigations on L2 production, the number of perceptual studies have also increased considerably in the Brazilian scenario. Still regarding final stops in English, Albuquerque (2012) investigated the perception of minimal pairs such as 'batbad' by Brazilian learners. The author concluded that both vowel duration and the voicing during the stop closure guided the perception of the words in these pairs, and that the degree of employment of these different cues depended on the place of articulation of the target consonant. Likewise, with regard to word-initial position, Alves and Motta (2014) and Alves and Zimmer (2015) showed that VOT is not the main acoustic cue employed by Brazilian learners in the identification and discrimination of minimal pairs such as 'pat-bat', and that a multitude of cues might be at play in L2 perception. This, once again, conforms to the dynamic theoretical perspective according to which language development emerges from the interaction of a multitude of factors.

Besides all the empirical research above, it is crucial to also consider the theoretical advancement on L2 development. Perozzo (2017 a, b), for instance, proposes a dynamic account of L2 perception that adopts the acoustic-articulatory gesture (cf. ALBANO, 2001) as the primitive unit of perception, arguing that such a representation is dynamic in its nature. In other words, the L2 studies carried out in the Brazilian context have contributed not only to an empirical description of L2 data, but also to sound theoretical growth in this field of knowledge.

If we are to conceive L2 perception under a dynamic perspective, we cannot dissociate it from a much larger construct: L2 intelligibility. Indeed, L2 intelligibility relies on speech perception, but it undeniably goes much further, since it is highly dependent on the multitude of factors that preclude the communication environment. Recent studies by Becker (2013), Dutra (2014), Schwartzhaupt (2015), Albuquerque and Alves (2017) and Delatorre (2017) have assumed this dynamic property of intelligibility. Becker (2013) shows that intelligibility is a construct that depends not only on the speaker, but also on 
the listener. In a recent study, Becker and Kluge (2015) and Gonçalves and Silveira (2015) showed that word frequency is also a factor that plays a role in intelligibility. Dutra (2014) considers intelligibility to be a dynamic construct with an emergent property. According to his account, intelligibility is not a pre-defined static construct, but it emerges based on all of those factors that characterize the environment at the moment of communication. This definition reinforces the complexity of this process, as the contents of the message, the participants and all the variables connected to the environment play a role in the establishment of this construct.

In the same line, Schwartzhaupt (2015) showed that not only accented pronunciation but also contextual information played a role in L2 intelligibility. In turn, Albuquerque and Alves (2017) have shown that listeners' familiarity with the speakers' L1 may play a significant role when performing a comprehensibility task. Finally, Delatorre (2017) showed an interplay between grapho-phonic-phonological effects (cf. ZIMMER; SILVEIRA; ALVES, 2009) and intelligibility, as the author showed that the pronunciation of the -ed marker, which tends to be produced with an epenthetic vowel due to the influence of spelling by Brazilian learners, may pose problems in intelligibility among Brazilian listeners. These results also conform to the assumption that a multitude of variables play an active role in L2 communication and may represent good evidence for pronunciation teaching.

We must also refer to studies on L2 development that investigated the role of explicit instruction ${ }^{4}$ or perceptual training in the classroom. Many recent studies have also shown the benefits of explicit instruction both in production (LIMA JR., 2008; ALVES; MAGRO, 2011; PEREYRON; ALVES, 2018) and in perception (PEROZZO, 2013; MOTTA; ALVES, 2013; MENDES, 2018). The role of perceptual training has also been investigated under a dynamic account, as in Brawerman-Albini (2012). These studies have shown that these classroom and laboratory practices play a relevant contribution to L2 speech development, but that this contribution should not be taken in an all-or-nothing fashion either. As an example, the data presented in Alves and Magro (2011) show that, although learners did not reach native-like values of aspiration in the production of word-initial $/ \mathrm{p} /$ (which, in a more traditional view, could lead researchers to consider that these stop segments had not been aspirated), explicit instruction contributed to an increase in VOT values in the target language. This increase should not be disregarded if we consider that instruction has contributed to approaching learners to the timing patterns of the target language.

4 For a characterization of the term 'explicit instruction', see the next section. 
- A dynamic perspective on L2 pronunciation development: bridging research and communicative teaching practice

Finally, it is undeniable that the dynamic view of language has given rise to a new methodological scenario regarding experimental techniques, data collection and analysis. As for new experimental techniques, studies by Correa (2017) and Correa and Ferreira Gonçalves (2017), for instance, have employed articulatory analyses in order to study the development of L2 French vowels by Brazilian learners. Lastly, with regard to data collection and analytical procedures, it is important to mention that, rather than group analyses, studies which focus on a single individual and his/her longitudinal development have been more and more frequent in the field (LOWIE; VERSPOOR, 2019, 2015; LOWIE, 2017), as this sort of study is able to capture the individual as a whole, his/her singularities and developmental trajectory in time. In the Brazilian scenario, Lima Jr. (2017, 2016 a, b) has defended a mixed approach, combining both group and learner individual analyses. In his studies of L2 vowel development, the author has shown that group inferential data and descriptive individual data complement each other by providing a richer description of learner development through time and of group tendencies. His final 8-semester-long longitudinal analysis of English vowel development by Brazilian learners will include a mixed-effects model (LIMA JR., 2019). These studies open new avenues in L2 research in Brazil, challenging researchers to invest in a more holistic approach to language development.

Considering that the aforementioned studies have shown positive effects brought about by instructional or training practices, we believe that more investigations are necessary in this subfield. Indeed, all of the studies cited in the paragraphs above investigated the effects of explicit instruction or perceptual training in terms of learners' accuracy or degree of accentedness. Given that the first and foremost objective of pronunciation instruction should be intelligibility, we recognize that studies that highlight the relationship between classroom practices and intelligibility prove important. Besides, studies that analyze language comprehensibility ${ }^{5}$ are also necessary. In this sense, we believe that this reflection may pave the way for a wide variety of future studies on the role of instruction in a dynamic perspective.

These facts considered, it is vital to discuss how pronunciation instruction can be addressed in the language classroom. We believe, in this sense, that a dynamic perspective on language development has a lot to contribute to language pedagogy as well. In what follows, we intend to discuss the teaching of L2 pronunciation in a dynamic perspective and to suggest a few guidelines to help language teachers incorporate pronunciation teaching to their communicative language teaching practice.

5 The term 'comprehensibility' may be understood "as a measure of how easy or difficult it is for a listener to understand a speaker's production (for example, even though a person may understand everything an interlocutor said, he or she may have had to expend a lot of effort)" (DERWING; MUNRO, 2015 a, p. 16). 


\section{L2 pronunciation teaching}

As we assume that L2 pedagogy is unarguably dependent on the results obtained from research and that a teacher's practice is, explicitly or not, guided by his/her views on second language development, it is important to discuss the implications of a dynamic perspective on L2 pronunciation teaching. In this section, we characterize L2 pronunciation instruction under a dynamic perspective, as well as how teaching and research, guided by this perspective, can contribute to each other.

Before addressing the techniques of pronunciation teaching themselves, we find it important to characterize a dynamic view of language teaching in general. As Verspoor (2017, p. 143) puts it, "if we assume that language is a complex adaptive system", as a consequence, "the teaching and learning is a dynamic process". With this in mind, formuse-meaning ${ }^{6}$ mappings should be the units of teaching, being these units interrelated and meaningful wholes, as they are seen in a holistic fashion. As stated in Larsen-Freeman (2015b), teaching is much more than providing input: it is to allow learners to build affordances from the communicative environment in the language classroom. In order for this scenario to take place, the phonetic-phonological subsystem, interconnected with other language subsystems, such as syntax, morphology, and pragmatics (among others), plays a pivotal role.

The discussion above proves pertinent when we discuss what the goals of pronunciation teaching are. This is far from being a naïve question, as the answer might vary even among researchers and linguists that do not share the same conception of language development. Following Derwing and Munro (2015 a, b) and Levis (2018), we claim that intelligibility should constitute the main goal of pronunciation teaching. Besides, pronunciation teaching may also contribute to higher levels of comprehensibility in the speaker-listener interaction. Under this view, the "learn pronunciation in order to sound like a native speaker of the language" principle should not be the goal of a pronunciation lesson. Indeed, it is undeniable that some degrees of accentedness might prove intelligible and comprehensible, and, for this reason, do not need to be eradicated in class. Besides, in a view of language that accepts variation and diversity to be inherent properties of all language systems, the idealized concept of a "native speaker" is highly elusive. Therefore, it is also the role of the informed foreign language teacher to help students set realistic and feasible goals concerning their phonological development in the L2.

6 Verspoor (2017, p. 145) proposes the use of the term Form-Use-Meaning-Mappings (FUMMs) "as it better captures the fundamental notion in a CDST that the 'units' are interrelated and meaningful wholes", in a way that formal units of language cannot be dissociated from their meaning and the pragmatic context in which they are used. 
- A dynamic perspective on L2 pronunciation development: bridging research and communicative teaching practice

Having intelligibility as our main goal in pronunciation teaching, we abandon an idealized view of language and conceive language in context, as language interaction is a fundamental aspect to indicate different degrees of intelligibility. This interactional view of language poses new demands on the pedagogical steps followed in pronunciation teaching, as they should be oriented toward a communicative goal.

For many years, L2 researchers have been discussing the need for an L2 pedagogy that is communicative in nature. However, there still seems to be disagreement or misunderstandings concerning what the term 'communicative' means. We believe that a characterization for this term also depends on the language perspective and the tenets of language development that researchers and teachers follow. With that in mind and considering a dynamic perspective, a communicative class should be one in which (i) all language items (syntactic, morphological, phonological) are integrated (LEVIS, 2018); (ii) there is a communicative goal or function to be fulfilled (KUPSKE; ALVES, 2017); and (iii) the completion of this communicative goal is highly dependent on the members of the interaction, as one interaction can never be the same as another, given that they are characterized by an emergent status.

Communicative lessons could also make use of explicit instruction. Following an emergent framework, Zimmer, Silveira and Alves (2009) say 'explicit instruction' can function as an umbrella term encompassing more than just the task of formally systematizing the linguistic system itself. Within a communicative framework, 'explicit instruction' includes the composite of other teaching procedures aiming to highlight, review or draw students' attention to specific aspects of the target language otherwise unnoticed by learners. In other words, the explicitation of a target L2 item should go far beyond its formal description - it should also encompass different opportunities for language practice, embedded in a communicative goal.

As we consider the teaching of L2 phonetics and phonology, it seems that the pronunciation skill still lags behind the teaching of other formal aspects of the target language. Even though much has already been said about communicative language teaching since the 1960s, the traditional 'listen and repeat' formula still tends to be the dominant practice in the teaching of L2 sounds. Besides, as pointed out in the analyses carried out by Bauer (2010), Bauer and Alves (2011), Alves and Machry da Silva (2013) and Alves (2015), many L2 course books are not successful in integrating pronunciation to their lessons. Pronunciation, in many cases, is presented as some sort of content that lies far apart from the rest of the course unit, and whose learning does not seem to contribute to the completion of the task proposed in that corresponding book chapter or unit. Teachers, in turn, might find it difficult to integrate pronunciation to their lessons, and might end 
up not including the phonetic-phonological aspects in their teaching. Besides this fact, it is also known that many teachers feel insecure when having to teach pronunciation (cf. SILVEIRA, 2016, 2004). All these factors contribute to an absence of pronunciation teaching in the L2 classroom, and to some feeling of hatred from students and teachers toward pronunciation.

As for the goal of teaching pronunciation communicatively, Celce-Murcia, Brinton and Goodwin (1996) and Celce-Murcia et al. (2010) suggest that a communicative pronunciation class should comprise five stages. We start by describing the first three stages, which should not be surprising to the reader, as they match traditional pronunciation teaching practices more closely. In the first stage, Description and Analysis, students have the chance to analyze language and elicit common patterns that would systematize the L2 system. In this stage, either deductive or inductive instruction is provided, and learners have the chance to infer, analyze and talk about language forms. In the second stage, Listening Discrimination, the learner is exposed to the L2 sounds. Since, as said in the previous sections, perception plays a fundamental role in the development of an L2 sound system, this stage is fundamental to the establishment of functional categories of sound distinctions in the L2. The third stage, called Controlled Practice and Feedback, consists of drills and mechanic practice; this is also important to help students master the articulation of the target sounds and develop automaticity.

The three stages described above do not necessarily need to be presented in this order. According to the authors, it is possible that the description and analysis stage be presented after listening discrimination, so that students can reach explicit conclusions about what they have just heard, for example. It is undeniable, however, that the three aforementioned stages have been used in pronunciation teaching for a long time, as they correspond to the traditional 'listen and repeat' approach. As Celce-Murcia, Brinton and Goodwin (1996) and Celce-Murcia et al. (2010) recognize the more traditional features of these first three stages, they propose two additional steps to their framework: Guided Practice and Feedback and Communicative Practice and Feedback. In the fourth stage, learners are presented to information gap activities: previously selected activities planned so that learners have to use the target L2 item in order to solve a communicative task. In other words, learners will only be able to exchange information and communicate properly if their speech is intelligible. Finally, Communicative Practice corresponds to the final pedagogical stage, in which learners have the opportunity to use language freely, without pre-selected vocabulary aspects or target items previously defined by the teacher. The use of the target item will be one of the many aspects students have to attend to; so they must be motivated to use the target items when communicating and solving the communicative task that has been proposed. 
- A dynamic perspective on L2 pronunciation development: bridging research and communicative teaching practice

As we recognize the relevance of the proposal by Celce-Murcia, Brinton and Goodwin (1996) and Celce-Murcia et al. (2010), we also acknowledge that a dynamic approach to L2 pronunciation teaching, while encompassing the five aforementioned stages, should also be concerned about the connection among these five steps. As Alves (2015) and Kupske and Alves (2017) point out, if followed in an isolated fashion, the five stages might end up representing no more than a Presentation-Practice-Production pedagogy. As we follow a dynamic perspective, integration is crucial. In order to integrate the five stages to each other, it is imperative that a communicative topic and communicative goals be set out. Besides, the integration which we advocate implies the connection of the teaching of pronunciation to the teaching of all other language skills. This derives from the fact that, when fulfilling a communicative goal, all language aspects should be attended. In other words, students should learn pronunciation as naturally as they can - there is no need to set aside 30 minutes of a class only to teach pronunciation. When using language, students are learning pronunciation, as well as all other language features and functions, all the time.

Having said that, we recognize that the traditional "pronunciation class" should not be an "official pronunciation class" any longer. Students should learn language, how to communicate, and how to solve a problem and complete a task by using the foreign language. In order to do so, pronunciation is as fundamental as the other language items; therefore, it should not be set apart in teaching. After all, language is a dynamic system, which emerges from the interaction of all its agents among themselves and with the environment. This premise conforms to a view of language as a Dynamic System (LARSEN-FREEMAN, 2017, 2015a, 2015b, 2014, 1997; CAMERON, 2003; LARSEN-FREEMAN; CAMERON, 2008; BECKNER et al., 2009; DE BOT, 2017, 2008; DE BOT; LOWIE; VERSPOOR, 2007; DE BOT et al., 2013; LOWIE, 2017; LOWIE;VERSPOOR, 2019, 2015): the lesson should be centered on the learners and should take into account their individual differences, their realities, interests and motivations. Indeed, it is impossible to separate the lesson plan from the realities of the learners, as they, and their interaction with each other and with their L2 developing system, turn the class into an emergent construct.

We recognize that integrating all language skills is not an easy task. In fact, as we conceive the L2 classroom as an environment in which emergent relations take place, there is no predefined recipe to learn from. It is true that the five stages proposed by CelceMurcia, Brinton and Goodwin (1996) and Celce-Murcia et al. (2010) may serve as some sort of guide in helping us organize the main components of pronunciation teaching, but, as already said, this is not enough if these steps are not integrated into a communicative theme or to the other language components. In this sense, it takes a lot of good sense, on 
the part of the teacher, to build integrated lessons, which help establish a communicative environment and, at the same time, account for the individualities of their learners.

Even though there is no recipe or formula to be followed, there is a great variety of pronunciation activities, games and techniques that can be easily integrated to L2 teaching. Barreto and Alves (2012) mention a variety of tasks that can help teachers integrate pronunciation to their lessons. Using songs and videos in the classroom may provide authentic material for the teaching of pronunciation, especially the teaching of intonational patterns. Songs may also represent a useful resource in the teaching of the International Phonetic Alphabet. Warm-ups and games, such as pronunciation bingos, may also make teaching more lively. Finally, we cannot disregard the fact that we live in a highly technological world. Pronunciation apps, online dictionaries, pronunciation websites and all sorts of audio material available on the internet may represent a great asset in pronunciation teaching. Furthermore, YouTube videos, in this sense, may be a great aid in the teaching of different varieties of English, in order to show students that English has become an international language and that intelligibility and accentedness correspond to two different constructs. By exposing learners to different varieties of English, native and non-native ones, we not only show them that there is no right or wrong dialect, but that intelligibility is a construct that is made of a multitude of factors, among which pronunciation is included. In sum, this teaching approach conforms to a view of Language as a Dynamic System, according to which a great number of variables is in action in the communication process.

Given the goal of integrating pronunciation to communicative topics, it is important that the teacher pre-select vocabulary items containing target aspects. It is, in fact, possible to conceive a list of communicative topics that match a pre-defined pronunciation item ${ }^{7}$. For example, fruits are a great opportunity to teach the vowels in English, especially the schwa. The discussion of birthdays (and a subsequent discussion on signs of the zodiac and personality) can be used in the teaching of ordinal numbers and of final - th. The distinction between tense [i:] and lax [I] can be addressed when discussing career choices (e.g. advertising, aviation, business adminnistration, information technologұ, criminal justice, information systems). This same topic could be used to address word-final $/ \mathrm{r}$ / sounds, as learners study the suffix -er in words such as 'teacher', 'driver' and 'dancer'. Personality traits as in adjectives ending in the suffixes -al and -ul (radical, practical, helpful, wonderful) can also be used in the teaching of the dark /I/, and so on.

7 Most of the communicative topics that are being suggested in this paragraph are based on Zimmer, Silveira and Alves (2009). 
- A dynamic perspective on L2 pronunciation development: bridging research and communicative teaching practice

These are just a few of the communicative topics which pronunciation can be integrated into, but this is definitely not an exhaustive list - many more connections between pronunciation aspects and vocabulary/communication topics may be thought of by the teacher. Our intention here was to show that the teaching of pronunciation does not demand "something extra" in our lesson plans - it just implies the ability of associating pronunciation teaching to activities we already do in the classroom. In other words, instead of learning how to add pronunciation, our challenge is to integrate pronunciation to the other aspects of the L2 curriculum. This integration is of paramount importance, as we conceive an approach that recognizes the interconnection of a multitude of aspects in language development and use.

\section{Final remarks}

After outlining the main characteristics of Complex Dynamic Systems to show that foreign language development is a dynamic system, we reviewed current pronunciationrelated research and proposed a few guidelines towards pronunciation teaching pedagogy. We divided this paper in the three sections above aiming to raise the readers' awareness of the need to incorporate research-based pronunciation teaching into their communicative language classes in an ongoing and integrated manner.

From the review on current research, the take-away lesson is that pronunciation development, as a dynamic system, is affected by innumerous variables, both learnerintrinsic, such as motivation, exposure to the L2, willingness to learn, etc., and learnerextrinsic, such as explicit pronunciation teaching. Therefore, one should not expect pronunciation development to occur linearly, in an "all or nothing" or "either presence or absence" fashion, but rather in a gradual, dynamic and sometimes quantic manner. One should also not underestimate the power of explicit pronunciation teaching, for one small perturbation in a dynamic system in a critical state might create a great change in the system, be it at the moment of teaching or later. It is also important to highlight the need of more studies on L2 sound production and perception, as well as on the role of explicit teaching.

From the pronunciation teaching pedagogy section, we would like to emphasize that it is the interaction of all agents characterizing the learner that causes the learner language to emerge. Therefore, the explicit teaching of pronunciation has an important role in the communicative language class, as long as it is integrated to the other skills in genuine communicative tasks. Lastly, being aware that there is no final state in foreign language development, the $\mathrm{L} 2$ teacher has the utmost role of helping students set realistic 
and feasible goals towards their pronunciation learning, based on intelligibility rather than on accent-free speech or on native-likeness. Once again, this new way of looking at pronunciation teaching is a result of an interaction of research findings and teaching practice, which should not be seen as separate constructs in L2 pedagogy.

\section{REFERENCES}

ALBANO, E. C. O gesto e suas bordas: esboço de fonologia acústico-articulatória do português brasileiro. Campinas: Mercado das Letras, 2001.

ALBUQUERQUE, J. I. A. Aspectos da percepção da dessonorização terminal do inglês por falantes nativos do português brasileiro. 2012. Dissertação (Mestrado em Letras) Setor de Humanidades, Universidade Federal do Paraná, Curitiba, 2012.

ALBUQUERQUE, J. I. A.; ALVES, U. K. Compreensibilidade em L2: uma discussão sobre o efeito da experiência do ouvinte e do tipo do meio em excertos do Português Brasileiro produzidos por um falante haitiano. REVISTA X, v. 12, p. 43-64, 2017.

ALVES, U. K. O ensino das fricativas coronais do português (LE) para falantes de espanhol (L1): análise de livro didático. In: SILVEIRA, R.; EMMEL, I. (org.). Um retrato do português como segunda língua: ensino, aprendizagem e avaliação. Campinas: Pontes, 2015. p. 7596.

ALVES, U. K.; MACHRY DA SILVA, S. M[e]nino ou m[i]nino? Bol[o] ou bol[u]? O tratamento das vogais do Português Brasileiro (LE) por manuais voltados a aprendizes argentinos. Linguagem \& Ensino, v. 16, n. 1, p. 131-153, 2013.

ALVES, U. K.; MAGRO, V. Raising awareness of L2 phonology: explicit instruction and the acquisition of aspirated /p/ by Brazilian Portuguese speakers. Letras de Hoje, v. 46, p. 7180, 2011.

ALVES, U. K.; MOTTA, C. S. Focusing on the right cue: perception of voiceless and voiced stops in English by Brazilian learners. Phrasis - Studies in Language and Literature, v. 50, p. 31-50, 2014. 
- | A dynamic perspective on L2 pronunciation development: bridging research and communicative teaching practice

ALVES, U. K.; ZIMMER, M. C. Percepção e produção dos padrões de VOT do inglês por aprendizes brasileiros: O papel de múltiplas pistas acústicas sob uma perspectiva dinâmica. Alfa Revista de Linguística, v. 59, p. 157-180, 2015.

BAK, P.; WEISSMAN, M. How Nature Works: The Science of Self-Organized Criticality. American Journal of Physics, v. 65, n. 6, p. 579-580, 1997.

BARBOZA, C. L. F. Efeitos da palatalização das oclusivas alveolares do Português Brasileiro no percurso de construção da fonologia do inglês língua estrangeira. 2013. Tese (Doutorado em Letras) - Centro de Humanidades, Universidade Federal do Ceará, Fortaleza, 2013.

BARRETO, F. M.; ALVES, U. K. Como inserir o ensino comunicativo de pronúncia na sala de aula de L2. In: LAMPRECHT, R. R. (org.). Consciência dos sons da língua: subsídios teóricos e práticos para alfabetizadores, fonoaudiólogos e professores de língua inglesa. 2. ed. Porto Alegre: EDIPUCRS, 2012. p. 231-258.

BATISTA, P. S. 'Niece' ou 'knees'? Produção da duração das vogais antecedentes a [s] e [z] finais no Inglês de aprendizes de Porto Alegre. 2018. Trabalho de Conclusão de Curso (Licenciatura em Letras) - Instituto de Letras, Universidade Federal do Rio Grande do Sul, Porto Alegre, 2018.

BAUER, D. A. O tratamento do aspecto fonético-fonológico na aula de inglês como LE: análise de um livro didático. 2010. Trabalho de Conclusão de Curso (Graduação em Letras) - Instituto de Letras, Universidade Federal do Rio Grande do Sul, Porto Alegre, 2010.

BAUER, D. A.; ALVES, U. K. O ensino comunicativo de pronúncia nas aulas de inglês (L2) para aprendizes brasileiros: análise de um livro didático. Linguagem \& Ensino, v. 14, n. 2, p. 287-314, 2011.

BECKER, M. R. Inteligibilidade da língua inglesa sob o paradigma de Língua Franca: percepção de discursos de falantes de diferentes L1s por brasileiros. 2013. Tese (Doutorado em Letras) - Setor de Humanidades, Universidade Federal do Paraná, Curitiba, 2013.

BECKER, M. R.; KLUGE, D. C. Frequência de uso de item e inteligibilidade do inglês como língua franca. Organon, v. 30, n. 58, p. 153-173, 2015. 
BECKNER, C.; ELLIS, N. C.; BLYTHE, R.; HOLLAND, J.; BYBEE, J.; KE, J.; CHRISTIANSEN, M. H.; LARSEN-FREEMAN, D.; CROFT, W.; SCHOENEMANN, T. Language is a Complex Adaptive System - Position Paper. Language Learning, v. 59, supl. 1, p. 1-26, 2009.

BLANK, C. A. A transferência grafo-fônico-fonológica em multilíngues falantes de português, espanhol e inglês: uma abordagem dinâmica. In: ALVES, U. K. (org.). Aquisição fonético-fonológica de língua estrangeira: investigações rio-grandenses e argentinas em discussão. Campinas: Pontes Editores, 2016. p. 209-228.

BLANK, C. A. A influência grafo-fonico-fonológica na produção oral e no processamento de priming em multilíngues: uma perspectiva dinâmica. 2013. Tese (Doutorado em Letras) - Escola de Humanidades, Universidade Católica de Pelotas, Pelotas, 2013.

BRAWERMAN-ALBINI, A. Os efeitos de um treinamento de percepção na aquisição do padrão acentual pré-proparoxítono da língua inglesa por estudantes brasileiros. 2012. Tese (Doutorado em Letras) - Setor de Humanidades, Universidade Federal do Paraná, Curitiba, 2012.

BROWMAN, C. P.; GOLDSTEIN, L. Dynamics and articulatory phonology. In: PORT, R. F.; van GELDER, T. (org.). Mind as motion: explorations in the dynamics of cognition. Boston: MIT Press, 1995. p. 175-193.

BROWMAN, C. P.; GOLDSTEIN, L. Articulatory phonology: An overview. Phonetica, v. 49, n. 3-4, p. 155-180, 1992.

BROWMAN, C. P.; GOLDSTEIN, L. Representation and reality: Physical systems and phonological structure. Haskins Laboratories Status Report on Speech Research, p. 8392, 1991.

BROWMAN, C. P.; GOLDSTEIN, L. Tiers in articulatory phonology, with some implications for casual speech. Papers in laboratory phonology I: Between the grammar and physics of speech, 1990. p. 341-376.

BROWMAN, C. P.; GOLDSTEIN, L. Gestural structures and phonological patterns. Haskins Laboratories Status Report on Speech Research, SR-97/98, p. 1-23, 1989a. 
- A dynamic perspective on L2 pronunciation development: bridging research and communicative teaching practice

BROWMAN, C. P.; GOLDSTEIN, L. Articulatory gestures as phonological units. Phonology, v. 6 , n. 2, p. 201-251, 1989b.

BROWMAN, C. P.; GOLDSTEIN, L. Some notes on syllable structure in articulatory phonology. Phonetica, v. 45, n. 2-4, p. 140-155, 1988.

CAMERON, L. Metaphor in educational discourse. London: Bloomsbury Publishing, 2003.

CELCE-MURCIA, M. (ed.). Teaching English as a Second or Foreign Language. 3. ed. Boston: Heinle \& Heinle Thomson Learning, 2001.

CELCE-MURCIA, M.; BRINTON, D. M.; GOODWIN, J. M. Teaching Pronunciation: a reference for teachers of English to speakers of other languages. Cambridge: Cambridge University Press, 1996.

CELCE-MURCIA, M.; BRINTON, D. M.; GOODWIN, J. M. GRINER, B. Teaching Pronunciation: a course book and reference guide. Cambridge: Cambridge University Press, 2010.

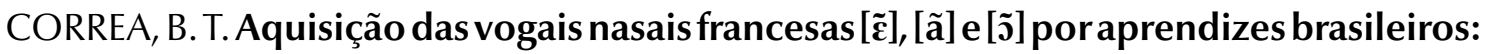
aspectos acústico-articulatórios. 2017. Dissertação (Mestrado em Letras) - Instituto de Letras, Universidade Federal de Pelotas, Pelotas, 2017.

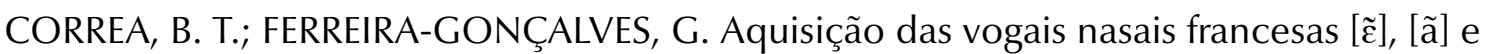
[̃] por aprendizes brasileiros: aspectos articulatórios. Ilha do Desterro, v. 70, n. 3, p. 131150, 2017.

COOPER, D. L. Linguistic attractors: The cognitive dynamics of language acquisition and change. v. 2. Amsterdam: John Benjamins Publishing, 1999.

CRISTÓFARO-SILVA; T.; CAMARGOS, M. A. Conhecimento fonológico e apropriação de róticos em inglês (L2) por falantes nativos de Português Brasileiro. Ilha do Desterro, v. 69, p. 49-60, 2016. 
CRISTÓFARO-SILVA; T.; RODRIGUES, J. V. A emergência da lateral pós-vocálica em inglês-L2 de falantes do Português Brasileiro. Organon, v. 30, n. 58, p. 33-48, 2015.

DE BOT, K. Complexity Theory and Dynamic Systems Theory: same or different? In: ORTEGA, L.; HAN, Z. (ed.). Complexity Theory and Language Development: in celebration of Diane Larsen-Freeman. Amsterdam: John Benjamins Publishing Company, 2017. p. 51-58.

DE BOT, K. Introduction: Second language development as a dynamic process. The Modern Language Journal, v. 92, n. 2, p. 166-178, 2008.

DE BOT, K.; LOWIE, W.; VERSPOOR, M. A Dynamic Systems Theory approach to second language acquisition. Bilingualism: Language and Cognition, v. 10, n. 1, p. 7-21, 2007.

DE BOT, K.; LOWIE, W.; THORNE, S. L.; VERSPOOR, M. Dynamic Systems Theory as a comprehensive theory of second language development. In: MAYO, M. P. G.; MANGADO, M. J. G.; ADRIÁN, M. M. Contemporary Approaches to Second Language Acquisition. Amsterdam: John Benjamins Publishing Company, 2013. p. 199-220.

DELATORRE, F. Intelligibility of English verbs ending in -ed for Brazilian learners of English as listeners. 2017. Tese (Doutorado em Língua Inglesa) - Centro de Comunicação e Expressão, Universidade Federal de Santa Catarina, Florianópolis, 2017.

DE LOS SANTOS, B. R. A produção da vogal átona final /e/ por Porto-Alegrenses aprendizes de Espanhol como Segunda Língua (L2): uma investigação sobre Atrito Linguístico em ambiente de L2 não-dominante. 2017. Dissertação (Mestrado em Letras) Instituto de Letras, Universidade Federal do Rio Grande do Sul, Porto Alegre, 2017.

DE LOS SANTOS, B. R.; ALVES, U. K. Explorando a possibilidade de atrito linguístico: uma análise acústica da produção da vogal átona final /e/ na variedade Porto-Alegrense do Português Brasileiro. Gradus: Revista Brasileira de Fonologia de Laboratório, v. 3, n. 1, p. 14-41, 2018.

DERWING, T. M.; MUNRO, M. J. The interface of teaching and research: What type of L2 pronunciation instruction should learners expect? In: LUCHINI, P. L.; GARCÍAJURADO, M. A.; ALVES, U. K. (ed.). Fonética y fonología: articulación entre enseñanza e investigación. Mar del Plata, Argentina, Universidad Nacional de Mar del Plata, 2015a. p. 14-26. 
- | A dynamic perspective on L2 pronunciation development: bridging research and communicative teaching practice

DERWING, T. M.; MUNRO, M. J. Pronunciation fundamentals - Evidence-based perspectives for $\mathrm{L} 2$ teaching and research. Amsterdam: John Benjamins, $2015 \mathrm{~b}$.

DUTRA, C. C. Intelligibility - an emergent fractal as evinced by in vivo assessment. 2014. Dissertação (Mestrado em Letras) - Instituto de Letras, Universidade Federal do Rio Grande do Sul, Porto Alegre, 2014.

ELLIS, N. C. Implicit and explicit language learning: their dynamic interface and complexity. In: REBUSCHAT, P. (ed.). Implicit and explicit learning of languages. Amsterdam: John Benjamins Publishing Company, 2015. p. 3-23.

ELLIS, N. C. Emergentism, connectionism and language learning. Language learning, v. 48, n. 4, p. 631-664, 1998.

ELMAN, J. L. Language as a dynamical system. In: PORT, R. F.; VAN GELDER, T. (ed.). Mind as motion: Explorations in the dynamics of cognition. Cambridge: MIT Press, 1995. p. 195223.

ENGELBERT, A. P. P. F. Diferenças de produção entre palavras CVC e CVCV do inglês por aprendizes brasileiros: uma análise acústica. In: BRAWERMAN-ALBINI, A.; GOMES, M. L. C. (org.). $\mathbf{O}$ jeitinho brasileiro de falar inglês: pesquisas sobre a pronúncia do inglês por falantes brasileiros. Campinas: Pontes, 2014. p. 143-156.

ENGELBERT, A. P. P. F.; SILVA, A. H. P. A produção da vogal final /i/ em dissílabos do inglês por aprendizes brasileiros - uma questão de tempo. Verba Volant, v. 3, n. 1, p. 72-83, 2012.

FERREIRA, A. P. P. Pet or petty? Diferenças entre palavras CVC e CVCV do inglês por aprendizes brasileiros: uma análise acústica. 2007. Dissertação (Mestrado em Letras) Setor de Humanidades, Universidade Federal do Paraná, Curitiba, 2007.

FLEGE, J. E. Second Language Speech Learning: Theory, findings, and problems. In: STRANGE, W. (ed.). Speech perception and linguistic experience: Issues in crosslanguage research. Timonium, MD: York Press, 1995. p. 233-277.

FRANÇA, K. V. A aquisição da aspiração. Curitiba: Editora Appris, 2015. 
FRANÇA, K. V. A aquisição da aspiração das plosivas surdas do inglês por falantes do Português Brasileiro: implicações teóricas decorrentes de duas diferentes formas de descrição de dados. 2010. Dissertação (Mestrado em Letras) - Escola de Humanidades, Universidade Católica de Pelotas, Pelotas, 2010.

GONÇALVES, A. R.; SILVEIRA, R. Frequency effects on the intelligibility of English words with high front vowels. Organon, v. 30, n. 58, p. 127-152, 2015.

HIVER, P. Attractor States. In: DÖRNYEI, Z.; MacINTYRE, P. D.; HENRY, A. (ed.). Motivational Dynamics in Language Learning. Bristol: Multilingual Matters, 2015. p. 20-28.

IRIE, K.; RYAN, S. Study abroad and the dynamics of change in learner L2 self-concept. Motivational dynamics in language learning, p. 343-366, 2015.

JOHNSON, K. Acoustics and auditory phonetics. Malden: Blackwell Publishing, 1997.

KELSO, J. A. S.; SALTZMAN, E. L.; TULLER, B. The dynamical perspective on speech production: Data and theory. Journal of Phonetics, v. 14, n. 1, p. 29-59, 1986.

KUPSKE, F. F. Imigração, Atrito e Complexidade: a produção das oclusivas surdas iniciais do Inglês e do Português por Sul-Brasileiros residentes em Londres. 2016. Tese (Doutorado em Letras) - Instituto de Letras, Universidade Federal do Rio Grande do Sul, Porto Alegre, 2016.

KUPSKE, F. F.; ALVES, U. K. Orquestrando o caos: o ensino de pronúncia de língua estrangeira à luz do paradigma da complexidade. Fórum Linguístico, v. 14, n. 4, p. 27712784, 2017.

LARSEN-FREEMAN, D. Complexity Theory: the lessons continue. In: ORTEGA, L.; HAN, Z. (ed.). Complexity Theory and Language Development: in celebration of Diane LarsenFreeman. Amsterdam: John Benjamins Publishing Company, 2017. p. 11-50.

LARSEN-FREEMAN, D. Ten 'Lessons' from Dynamic Systems Theory: what is on offer. In: DÖRNYEI, Z.; MacINTYRE, P. D.; HENRY, A. (ed.). Motivational Dynamics in Language Learning. Bristol: Multilingual Matters, 2015a. p. 11-19. 
- | A dynamic perspective on L2 pronunciation development: bridging research and communicative teaching practice

LARSEN-FREEMAN, D. Complexity theory. In: VAN PATTEN, B.; WILLIAMS, J. (ed.). Theories in Second Language Acquisition. 2. ed. Londres: Routledge, 2015b. p. 227-244.

LARSEN-FREEMAN, D. It's about time. The Modern Language Journal, v. 98, n. 2, p. 665666, 2014.

LARSEN-FREEMAN, D. Chaos/complexity science and second language acquisition. Applied Linguistics, v. 18, n. 2, p. 146-165, 1997.

LARSEN-FREEMAN, D.; CAMERON, L. Complex Systems and Applied Linguistics. Oxford University Press, 2008.

LEVIS, J. Intelligibility, oral communication, and the teaching of pronunciation. Cambridge: Cambridge University Press, 2018.

LIMA JR., R. M. A longitudinal study on the acquisition of six English vowels by Brazilian learners. In: Proceedings of the 19th International Congress of Phonetic Sciences (ICPhS), Melbourne, Australia, 2019. Canberra: Australasian Speech Science and Technology Association Inc., 2019. p. 3180-3184.

LIMA JR., R. M. The influence of metalinguistic knowledge of segmental phonology on the production of English vowels by Brazilian undergraduate students. Ilha do Desterro, v. 70, n. 3, p. 117-130, 2017.

LIMA JR., R. M. A necessidade de dados individuais e longitudinais para análise do desenvolvimento fonológico de L2 como sistema complexo. Revista Virtual de Estudos da Linguagem, v. 14, n. 27, p. 203-225, 2016a.

LIMA JR., R. M. Análise longitudinal de vogais do inglês-L2 de brasileiros. Gradus: Revista Brasileira de Fonologia de Laboratório, v. 1, n. 1, p. 145-176, 2016 b.

LIMA JR., R. M. A influência da idade da aquisição de seis vogais do inglês por alunos brasileiros. Organon, v. 30, n. 58, p. 15-31, 2015.

LIMA JR., R. M. A influência da idade na aquisição da fonologia do inglês como língua estrangeira por brasileiros. 2012. Tese (Doutorado em Letras) - Instituto de Letras, Universidade de Brasília, Brasília, 2012. 
LIMA JR., R. M. Pronunciar para comunicar: uma investigação do efeito do ensino explícito da pronúncia na sala de aula de LE. 2008. Dissertação (Mestrado em Letras) Instituto de Letras, Universidade de Brasília, Brasília, 2008.

LORENZ, E. Predictability: does the flap of a butterfly's wing in Brazil set off a tornado in Texas? Annual meeting of the American Association for the Advancement of Science. Washington, DC: 1972

LOWIE, W. Lost in state space? Methodological considerations in Complex Dynamic Theory approaches to second language development research. In: ORTEGA, L.; HAN, Z. (ed.). Complexity Theory and Language Development: in celebration of Diane LarsenFreeman. Amsterdam: John Benjamins Publishing Company, 2017. p. 123-141.

LOWIE, W.; VERSPOOR, M. Individual differences and the ergodicity problem. Language Learning, v. 69, s. 1, p. 184-205, 2019.

LOWIE, W.; VERSPOOR, M. Variability and variation in Second Language Acquisition orders: a dynamic reevaluation. Language Learning, v. 65, n. 1, p. 63-88, 2015.

MacINTYRE, P. D.; MacKAY, E.; ROSS, J.; ABEL, E. The emerging need for methods appropriate to study dynamic systems: individual differences in motivational dynamics. In: ORTEGA, L.; HAN, Z. (ed.). Complexity Theory and Language Development: in celebration of Diane Larsen-Freeman. Amsterdam: John Benjamins Publishing Company, 2017. p. 97-122.

MENDES, T. R. O efeito da instrução explícita de sândis externos da língua inglesa no desenvolvimento da percepção auditiva de aprendizes brasileiros. 2018. Dissertação (Mestrado em Linguística) - Centro de Humanidades, Universidade Federal do Ceará, Fortaleza, 2018.

MOTTA, C. S.; ALVES, U. K. Efeitos da instrução explícita na percepção de padrões de VOT por aprendizes brasileiros de inglês. Trabalho apresentado no IV SAF - Seminário de Aquisição Fonológica. Santa Maria, 2013.

MUNRO, M. J.; DERWING, T. Intelligibility in Research and Practice: Teaching Priorities. In: REED, M.; LEVIS, J. M. (ed.). The Handbook of English Pronunciation. Malden, MA: Wiley Blackwell, 2015. p. 377-396. 
- | A dynamic perspective on L2 pronunciation development: bridging research and communicative teaching practice

NASCIMENTO, K. R. S. Emergência de padrões silábicos no Português Brasileiro e seus reflexos no Inglês Língua Estrangeira. 2016. Tese (Doutorado em Letras) - Centro de Humanidades, Universidade Estadual do Paraná, Curitiba, 2016.

PEREYRON, L. A produção vocálica por falantes de Espanhol (L1), Inglês (L2) e Português (L3): uma perspectiva dinâmica na (multi) direcionalidade da transferência linguística. 2017. Tese (Doutorado em Letras) - Instituto de Letras, Universidade Federal do Rio Grande do Sul, Porto Alegre, 2017.

PEREYRON, L.; ALVES, U. K. Efeitos da instrução articulatória das vogais médias baixas do português (L3) no espanhol (L1) e no inglês (L2): um estudo de caso. Brazilian English Language Teaching, v. 9, n. 1, p. 167-189, 2018.

PEREYRON, L.; ALVES, U. K. A transferência vocálica em falantes bilíngues e trilíngues: uma concepção de Língua como Sistema Adaptativo Complexo. Revista Virtual de Estudos da Linguagem, v. 14, n. 27, p. 226-265, 2016.

PEROZZO, R. V. Sobre as esferas cognitiva, acústico-articulatória e realista indireta da percepção fônica não-nativa: para além do PAM-L2. 2017. Tese (Doutorado em Letras) Instituto de Letras, Universidade Federal do Rio Grande do Sul, Porto Alegre, 2017a.

PEROZZO, R. V. Percepção fônica de línguas não nativas no arcabouço da cognição e do realismo indireto: complementaridade entre aspectos cognitivos e filosóficos a partir do PAM-L2. Gradus: Revista Brasileira de Fonologia de Laboratório, v. 2, n. 1, p. 52-72, 2017b.

PEROZZO, R. V. Percepção de oclusivas não-vozeadas sem soltura audível em codas finais do inglês (L2) por brasileiros: o papel da instrução explícita e do contexto fonéticofonológico. 2013. Dissertação (Mestrado em Letras) - Instituto de Letras, Universidade Federal do Rio Grande do Sul, Porto Alegre, 2013.

PORT, R. F. Dynamical systems hypothesis in cognitive science. Encyclopedia of cognitive science, 2002.

PORT, R. F.; VAN GELDER, T. Mind as motion: Explorations in the dynamics of cognition. Cambridge: MIT press, 1995. 
PRESTES, S. P. C. Produção de oclusivas iniciais do inglês por falantes do PB. 2013. Dissertação (Mestrado em Letras) - Setor de Humanidades, Universidade Federal do Paraná, Curitiba, 2013.

RICHARDS, J. C.; RENANDYA, W. A. (ed.). Methodology in Language Teaching - An Anthology of Current Practice. Cambridge: Cambridge University Press, 2002.

SALTZMAN, E.; KELSO, J. A. Skilled actions: a task-dynamic approach. Psychological review, v. 94, n. 1, p. 84, 1987.

SCHERESCHEWSKY, L. C.; ALVES, U. K.; KUPSKE, F. F. First language attrition: the effects of English (L2) on Brazilian Portuguese VOT patterns in an L1-dominant environment. Letrônica, v. 10, n. 2, p. 700-716, 2017.

SCHWARTZHAUPT, B. M. Testing intelligibility in English - the effects of positive VOT and contextual information in a sentence transcription task. 2015. Dissertação (Mestrado em Letras) - Instituto de Letras, Universidade Federal do Rio Grande do Sul, Porto Alegre, 2015.

SCHWARTZHAUPT, B. M. Factors Influencing Voice Onset Time: analyzing Brazilian Portuguese, English and interlanguage data. 2012. Trabalho de Conclusão de Curso (Licenciatura em Letras) - Instituto de Letras, Universidade Federal do Rio Grande do Sul, Porto Alegre, 2012.

SILVA, A. H. P. Pela incorporação de informação fonética aos modelos fonológicos. Revista Letras, v. 60, p. 319-333, 2003.

SILVEIRA, R. The influence of pronunciation instruction on the perception and the production of English word-final consonants. v. 11. Advanced Research in English Series. Florianópolis: DLLE/CCE/UFSC, 2016.

SILVEIRA, R. The influence of pronunciation instruction on the perception and the production of English word-final consonants. 2004. Tese (Doutorado em Letras). - Centro de Comunicação e Expressão, Universidade Federal de Santa Catarina, Florianópolis, 2004. 
- | A dynamic perspective on L2 pronunciation development: bridging research and communicative teaching practice

THELEN, E.; SMITH, L. B. A dynamic systems approach to the development of cognition and action. Cambridge: MIT Press, 1994.

VERSPOOR, M. Complex Dynamic Systems Theory and L2 pedagogy: lessons to be learned. In: ORTEGA, L.; HAN, Z. (ed.). Complexity Theory and Language Development: in celebration of Diane Larsen-Freeman. Amsterdam: John Benjamins Publishing Company, 2017. p. 209-231.

VERSPOOR, M. Initial Conditions. In: DÖRNYEI, Z.; MacINTYRE, P. D.; HENRY, A. (ed.). Motivational Dynamics in Language Learning. Bristol: Multilingual Matters, 2015. p. 3846.

VERSPOOR, M.; LOWIE, W.; VAN DIJK, M. Variability in second language development from a dynamic systems perspective. The Modern Language Journal, v. 92, n. 2, p. 214-231, 2008.

ZIMMER, M. C.; ALVES, U. K. Uma visão dinâmica da produção da fala em L2: o caso da Dessonorização Terminal. Revista da Abralin, v. 11, n. 1, p. 221-272, 2012.

ZIMMER, M. C.; ALVES, U. K. Learning to orchestrate time: voicing patterns and gestural drift in L2 speech production. São Paulo School of Advanced Studies in Speech Dynamics - Abstracts, São Paulo, p. 47-48, 2010.

ZIMMER, M. C.; SILVEIRA, R.; ALVES, U. K. Pronunciation Instruction for Brazilians: Bringing Theory and Practice Together. Cambridge: Cambridge Scholars Publishing, 2009.

COMO CITAR ESTE ARTIGO: LIMA JR., Ronaldo Mangueira; ALVES, Ubiratã Kickhöfel. A dynamic perspective on L2 pronunciation development: bridging research and communicative teaching practice. Revista do GEL, v. 16, n. 2, p. 2756, 2019. Disponível em: https://revistadogel.gel.org.br/

DOI: http://dx.doi.org/10.21165/gel.v16i2.2417

Submetido em: 20/11/2018 | Aceito em: 20/11/2019. 